\title{
Leucine Kinetics during Feeding in Normal Newborns
}

\author{
SCOTT C. DENNE, ELENA M. ROSSI, AND SATISH C. KALHAN \\ Division of Neonatology, Department of Pediatrics, Indiana University School of Medicine, \\ Indianapolis, Indiana 46202-5210 and Case Western Reserve University School of Medicine, \\ Cleveland, Ohio 44106
}

\begin{abstract}
To examine how leucine and protein metabolism is affected by feeding, leucine kinetics were determined in 11 normal term newborns during feeding using a prime constant tracer infusion of $1{ }^{13} \mathrm{C}$ leucine combined with respiratory calorimetry. Fed newborns were compared with previously studied fasting newborns. Feeding and fasting newborns had similar rates of leucine oxidation (34 $\pm 3 \mu \mathrm{mol} / \mathrm{kg} / \mathrm{h}$ versus $31 \pm 4 \mu \mathrm{mol} / \mathrm{kg} / \mathrm{h}$ ) and leucine release from existing protein $(156 \pm 16 \mu \mathrm{mol} / \mathrm{kg} / \mathrm{h}$ versus $164 \pm 8$ $\mu \mathrm{mol} / \mathrm{kg} / \mathrm{h})$. In contrast, nonoxidative disposal rates of leucine (a reflection of protein synthesis) were significantly greater in feeding newborns $(170 \pm 13 \mu \mathrm{mol} / \mathrm{kg} / \mathrm{h}$ versus $129 \pm 9 \mu \mathrm{mol} / \mathrm{kg} / \mathrm{h})$. A significant positive correlation between birth weight and leucine flux was demonstrated in both feeding and fasting newborns. These results suggest that 1) newborns may accomplish protein accretion primarily by increases in protein synthesis rather than suppression of protein breakdown; 2) an estimate can be made of the minimal leucine intake required to replace irreversible leucine oxidative losses $(816 \mu \mathrm{mol} / \mathrm{kg} / \mathrm{d}, 107$ $\mathrm{mg} / \mathrm{kg} / \mathrm{d}$ ); and 3 ) the positive correlation between birth weight and leucine flux in both feeding and fasting newborns may be a result of differences in previous protein and energy supplies. (Pediatr Res 30: 23-27, 1991)
\end{abstract}

\section{Abbreviations}

KIC, $\alpha$-ketoisocaproate

MPE, moles percent excess

In addition to providing specific information about the metabolism of an essential amino acid, leucine kinetic measurements may also reflect how different circumstances affect overall protein kinetics (1). In particular, these measurements have been used to assess the changes in proteolysis and protein synthesis in response to feeding after a period of fasting (2-7). Although the effects of feeding and fasting on leucine kinetics have been examined in normal adults (2-7), how feeding affects leucine metabolism in normal newborns has not been determined. Adults during feeding must accrete protein in sufficient quantity to replenish protein losses during fasting; in contrast, newborns must not only replace fasting losses but accumulate additional protein to accomplish growth. Therefore, feeding may result in different protein kinetic responses in newborns than in adults.

Received August 28, 1990; accepted February 22, 1991

Correspondence and reprint requests: Scott C. Denne, M.D., Indiana University School of Medicine, Department of Pediatrics, Section of Neonatal-Perinatal Medicine, 702 Barnhill Dr., RR208, Indianapolis, IN 46202-5210.

Supported in part by Diabetes Research Training Center NIH Grant PHS P60DK20542-13 and NIH Grant K08HD840-03, HD 11089, and by The James Whitcomb Riley Memorial Association.
We have previously determined leucine kinetics in fasting normal term newborns and demonstrated higher rates of leucine flux and oxidation compared to normal fasting adults (8). In addition, a significant correlation between newborn birth weight and leucine flux was demonstrated, suggesting a relationship between birth weight and fasting protein metabolism.

The purpose of our present study was to determine the effect of feeding on leucine kinetics in normal term newborns and to examine the relationship between birth weight and leucine kinetics during feeding. By comparing leucine kinetics during feeding with those previously measured during fasting, some insight into the normal process of protein accumulation in newborns could be gained. In addition, leucine oxidation measurements obtained in both feeding and fasting provide a quantitative basis to estimate leucine requirements in normal newborns.

\section{MATERIALS AND METHODS}

Study protocol. Eleven normal newborns were studied for 7 to $8 \mathrm{~h}$ during the first $3 \mathrm{~d}$ of life. All babies were full term, had not experienced birth asphyxia, had not received antibiotics, and had normal physical examinations with no apparent clinical problems. Studies were begun 3 to $4 \mathrm{~h}$ after the babies' last normal feeding. Clinical characteristics of the study subjects are shown in Table 1. All infants were studied under neurothermal conditions, and a skin temperature of $36^{\circ} \mathrm{C}$ was maintained under a servo-controlled radiant warmer. Beginning 3 to $4 \mathrm{~h}$ before the isotope infusion, $4 \mathrm{~mL} / \mathrm{kg}$ of standard infant formula (Enfamil; Mead Johnson, Evansville, IN) were carefully measured, placed in a small bottle, and fed to the baby orally every hour. This amount of formula corresponds to $1.44 \mathrm{~g} / \mathrm{kg} / \mathrm{d}$ of protein, 64 $\mathrm{kcal} / \mathrm{kg} / \mathrm{d}$, and $47 \mu \mathrm{mol} / \mathrm{kg} / \mathrm{h}$ of leucine. This rate of feeding was chosen because it provides a quantity of leucine that approximates estimated infant requirements $(\sim 150 \mathrm{mg} / \mathrm{kg} / \mathrm{d})(9)$. The bottle was weighed before and after each feeding to determine the actual intake. After 3 to $4 \mathrm{~h}$ of feeding, an indwelling needle was placed in a superficial vein of each arm to infuse the isotopic tracer in one and draw blood samples from the other. After a 4$\mu \mathrm{mol} / \mathrm{kg}$ priming dose, $1-{ }^{13} \mathrm{C}$ leucine (99 atom percent excess ${ }^{13} \mathrm{C}$; Merck Sharp and Dohme, Quebec, Canada) was infused at a constant rate of $6 \mu \mathrm{mol} / \mathrm{kg} / \mathrm{h}$ for the next $5 \mathrm{~h}$. At the end of each study, the actual rate of infusion was measured using the same syringe, i.v. tubing, and butterfly needle used with that particular study. The infusate concentration was also measured. Blood samples were obtained at $0.5-$ to 1.0 -h intervals. Steady state determinations of ${ }^{13} \mathrm{C}$ enrichment of bicarbonate and plasma leucine, obtained in the last $2 \mathrm{~h}$ of the study, were used for calculation of leucine kinetics. We have previously determined that ${ }^{13} \mathrm{C}$ enrichment measurements in bicarbonate and breath $\mathrm{CO}_{2}$ yield equivalent results $(10)$.

The plasma enrichment of leucine was used in these studies to calculate rates of leucine flux and oxidation. Plasma enrichment 
Table 1. Clinical characteristics

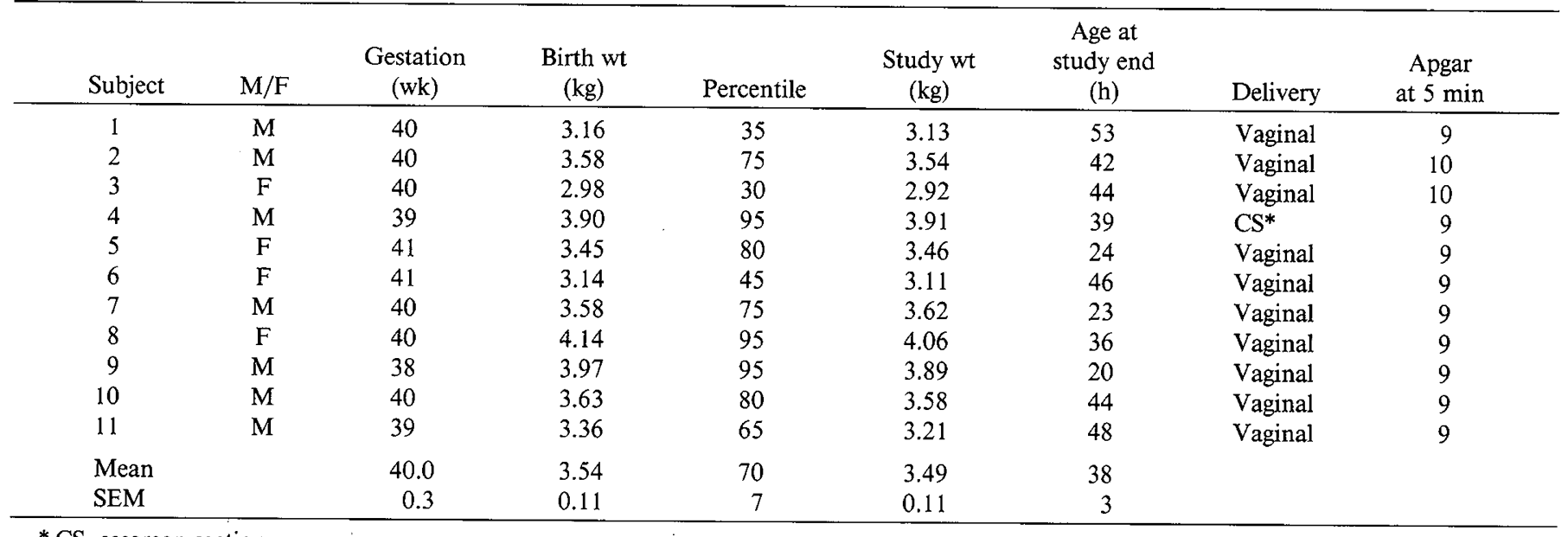

* CS, cesarean section.

of $\mathrm{KIC}$ instead of leucine has been suggested for the calculation of oxidation (11), and some authors have advocated the use of KIC enrichment for the determination of leucine flux as an index of intracellular leucine enrichment (12). Because KIC enrichment is lower than leucine enrichment, the use of plasma leucine enrichment may underestimate total body leucine flux. However, the constant infusion of $1-{ }^{13} \mathrm{C}$ leucine over a wide range of dietary intake and clinical circumstances has been shown to result in a constant ratio of KIC to leucine enrichment of approximately $0.77(11,13)$. Most pertinently, the KIC to leucine enrichment ratio was similar in adult humans studied during feeding and fasting (11). However, in studies of starved and fed rats, the ratio of plasma KIC to leucine enrichment was slightly (but not statistically) lower in the fed state $(0.72$ versus 0.76$)$ (14). Relative to fasting, this would slightly increase leucine oxidation in the fed state if based on KIC rather than leucine enrichment. Nevertheless, the use of KIC instead of leucine for calculating flux and oxidation in the present study would probably result in a proportional increase in values but would likely alter none of the relative findings.

Resting oxygen consumption and $\mathrm{CO}_{2}$ production were measured using open circuit indirect respiratory calorimetry as previously described $(8,10)$. Combustion of absolute ethyl alcohol in the system gave results within $5 \%$ of expected values. Respiratory calorimetry was performed throughout the study, and values obtained in the last $2 \mathrm{~h}$ were used for analyses. Subjects were quiet or sleeping for all measurements. The protocol was approved by the hospital committee on human investigation, and written informed consent was obtained from the babies' parents after fully explaining the procedure.

Analytical procedures. ${ }^{13} \mathrm{C}$ enrichment of plasma leucine was measured according to the method of Adams (15), with certain modifications, as described previously (16). The isotope abundance was calculated on each sample: $\{(\mathrm{m}+1) /[\mathrm{m}+(\mathrm{m}+1)]\}$. 100. MPE was then determined by subtracting the baseline enrichment. Final MPE was based on a standard curve constructed by mixing weighed amounts of labeled and unlabeled leucine (17).

The ${ }^{13} \mathrm{C}$ enrichment of $\mathrm{CO}_{2}$ in blood bicarbonate was measured after separation of the $\mathrm{CO}_{2}$ by cryogenic distillation in vacuum as previously described $(10,18)$. Plasma glucose was determined by the glucose oxidase method using a glucose analyzer (Yellow Springs Instrument Co., Yellow Springs, $\mathrm{OH}$ ). Amino acid concentrations were measured on a Beckman 6300 amino acid analyzer.

Calculations. The rate of leucine turnover was calculated by tracer dilution, applying steady state kinetics as modified for stable isotopic tracers $(17,19)$.

$$
\mathrm{Q}=\left[\frac{100}{\mathrm{Ep}}-1\right] \times \mathrm{I}
$$

where $\mathrm{Q}$ is leucine turnover or flux $(\mu \mathrm{mol} / \mathrm{kg} / \mathrm{h})$, Ep is ${ }^{13} \mathrm{C}$ enrichment of leucine in plasma at steady state (MPE), and I is rate of tracer infusion $(\mu \mathrm{mol} / \mathrm{kg} / \mathrm{h})$.

Oxygen consumption and $\mathrm{CO}_{2}$ production were calculated by multiplying the gradients and the flow rates of air across the face using Haldane transformation and corrected to the stp. The basal caloric expenditure was calculated from the $R Q$ and oxygen consumption data (20).

The fraction of leucine oxidized $(\mathrm{F})$ was assessed by determining the amount of infused label that appeared in $\mathrm{CO}_{2}$. The following equation was used (16):

$$
\mathrm{F}=\frac{\dot{\mathrm{V}}_{2} \times{ }^{13}\left[\mathrm{C}_{\mathrm{O}} \mathrm{O}_{2}\right.}{\mathrm{I} \times 0.8}
$$

where $\dot{\mathrm{V}} \mathrm{CO}_{2}$ is the carbon dioxide production and the constant 0.8 represents the fractional recovery of ${ }^{13} \mathrm{CO}_{2}(21,22)$. Leucine oxidation was then calculated by multiplying the leucine flux by the fraction of leucine flux oxidized.

A single value for the fractional ${ }^{13} \mathrm{CO}_{2}$ recovery has been used here. However, in parenterally fed premature newborns, a range of recovery of labeled $\mathrm{CO}_{2}$ has been obtained $(0.70-0.84)$ and a correlation observed between ${ }^{13} \mathrm{CO}_{2}$ recovery rates and energy intake. If the same relationship exists for fed and fasted normal term newborns, it is possible that using a constant value for recovery may slightly underestimate leucine oxidation in the fasted state and overestimate oxidation in the fed state. If these errors exist, protein synthesis estimates would be undervalued during feeding and overvalued during fasting.

All data are expressed as mean \pm SEM. Analysis of variance was used for comparisons.

\section{RESULTS}

Plasma amino acid concentrations determined at the end of the study period are shown in Table 2 . The results are within the range of values previously reported for normal newborns (23). Plasma glucose concentrations remained constant throughout the $5 \mathrm{~h}$ isotope infusion $(4.8 \pm 0.2 \mathrm{mM}$ at time $0,4.4 \pm 0.1 \mathrm{mM}$ at $300 \mathrm{~min}$ ).

Actual intakes of energy and protein during the study are shown in Table 3 . In addition, oxygen consumption, $\mathrm{CO}_{2}$ production, $R Q$, and energy expenditure determinations in fed, normal newborns are also presented. These values are consistent with other measurements in normal newborns (24).

The isotopic enrichments of leucine and $\mathrm{CO}_{2}$ measured during 
Table 2. Amino acid concentrations in normal newborns during feeding

\begin{tabular}{|c|c|}
\hline Amino acid & $\mu \mathrm{mol} / \mathrm{L}$ \\
\hline Aspartic acid & $13 \pm 2$ \\
\hline Throenine & $131 \pm 14$ \\
\hline Serine & $170 \pm 14$ \\
\hline Asparagine & $32 \pm 7$ \\
\hline Glutamic acid & $373 \pm 107$ \\
\hline Glutamine & $554 \pm 140$ \\
\hline Proline & $168 \pm 10$ \\
\hline Glycine & $264 \pm 14$ \\
\hline Alanine & $234 \pm 23$ \\
\hline Valine & $106 \pm 3$ \\
\hline 1/2 Cystine & $14 \pm 5$ \\
\hline Methionine & $32 \pm 2$ \\
\hline Isoleucine & $48 \pm 2$ \\
\hline Leucine & $84 \pm 3$ \\
\hline Tyrosine & $74 \pm 8$ \\
\hline Phenylalanine & $53 \pm 2$ \\
\hline Tryptophan & $46 \pm 4$ \\
\hline Lysine & $139 \pm 11$ \\
\hline Histidine & $78 \pm 3$ \\
\hline Arginine & $50 \pm 4$ \\
\hline
\end{tabular}

the studies are shown in Figure 1 (mean \pm SEM). Steady state was achieved for $1{ }^{13} \mathrm{C}$ leucine enrichment at $2 \mathrm{~h}$ and for ${ }^{13} \mathrm{CO}_{2}$ at $3 \mathrm{~h}$. The coefficient of variation of leucine enrichment at plateau was $7 \%$.

Leucine kinetic determinations in newborns during feeding as well as those previously determined during fasting $(8)$ are shown in Table 4. Previously reported fasting normal newborns $(n=$ 12) were studied under an identical protocol except for the absence of feeding (total fast $9.4 \pm 0.2 \mathrm{~h}$ ) (8). The age at study $(37 \pm 5 \mathrm{~h})$ and birth weight $(3.24 \pm 0.12 \mathrm{~kg})$ were similar to newborns studied during feeding. As expected, leucine flux was significantly greater in newborns during feeding. Leucine oxidation rates as well as the rate of leucine release from protein breakdown were similar in both groups. In contrast, rates of nonoxidative disposal of leucine (a reflection of protein synthesis) were significantly greater in feeding newborns.

A significant positive correlation was demonstrated between birth weight and leucine flux in normal newborns during feeding (Fig. 2). This is consistent with our previous observation of a similar correlation between birth weight and leucine flux in normal newborns obtained during fasting (8). Leucine flux is equivalent to leucine release from protein breakdown during fasting; therefore, by definition there is also a correlation between birth weight and leucine from protein breakdown in fasting newborns (8). A similar significant positive correlation was observed in the present study between birth weight and leucine from protein breakdown in fed newborns $(\mathrm{y}=88 \mathrm{x}-156, r=$ $0.62, p<0.05$ ).

No correlation was demonstrated between leucine oxidation and birth weight. In contrast to some studies in adults (16), no correlation was observed between leucine oxidation and leucine concentration in our present study. This may have been a result of the rather narrow range of leucine concentrations measured under the study conditions.

\section{DISCUSSION}

In our present study, we determined leucine kinetics in normal, full-term newborns within several days of birth during a period of small, hourly feedings. Rates of leucine release from endogenous protein and leucine oxidation are similar to those obtained in previously studied normal newborns during fasting. In contrast, the nonoxidative disposal rate of leucine (as indication of protein synthesis) was significantly greater in newborns studied during fasting. As has previously been demonstrated in fasting newborns, the data in our present study show a significant correlation between newborn birth weight and leucine flux, suggesting a relationship between birth weight and protein metabolism.

In an effort to understand whether protein accretion occurs as a result of increased rates of protein synthesis or suppression of protein breakdown, leucine kinetics have been measured during periods of fasting and feeding in a number of studies in human adults (2-7). With one exception (4), all studies have determined a reduced rate of release of leucine from endogenous protein during periods of feeding, suggesting that feeding-induced suppression of protein breakdown plays a primary role in protein retention in adults (4).

Conflicting results have been obtained regarding the effect of feeding on protein synthesis. Rennie et al. (4) demonstrated only changes in protein synthesis in response to feeding, whereas other investigators have shown increases in protein synthesis in combination with reductions in rates of protein breakdown $(3,5)$. However, some groups have not been able to demonstrate any changes in protein synthesis in response to feeding (2-7). Although each of these studies was performed somewhat differently, the variable conclusions regarding the effect of feeding on protein synthesis cannot be easily explained on the basis of study design, (paired versus cross-sectional), type of isotope $\left(1-{ }^{14} \mathrm{C}\right.$ leucine versus $1-{ }^{13} \mathrm{C}$ leucine), measured isotope enrichment (leucine versus $\mathrm{KIC}$ ), route of isotope administration (oral versus i.v.), or isotope recycling (7).

In contrast to most of the adult studies, the present study has

Table 3. Energy and protein intake and respiratory calorimetry data in fed, normal newborns.

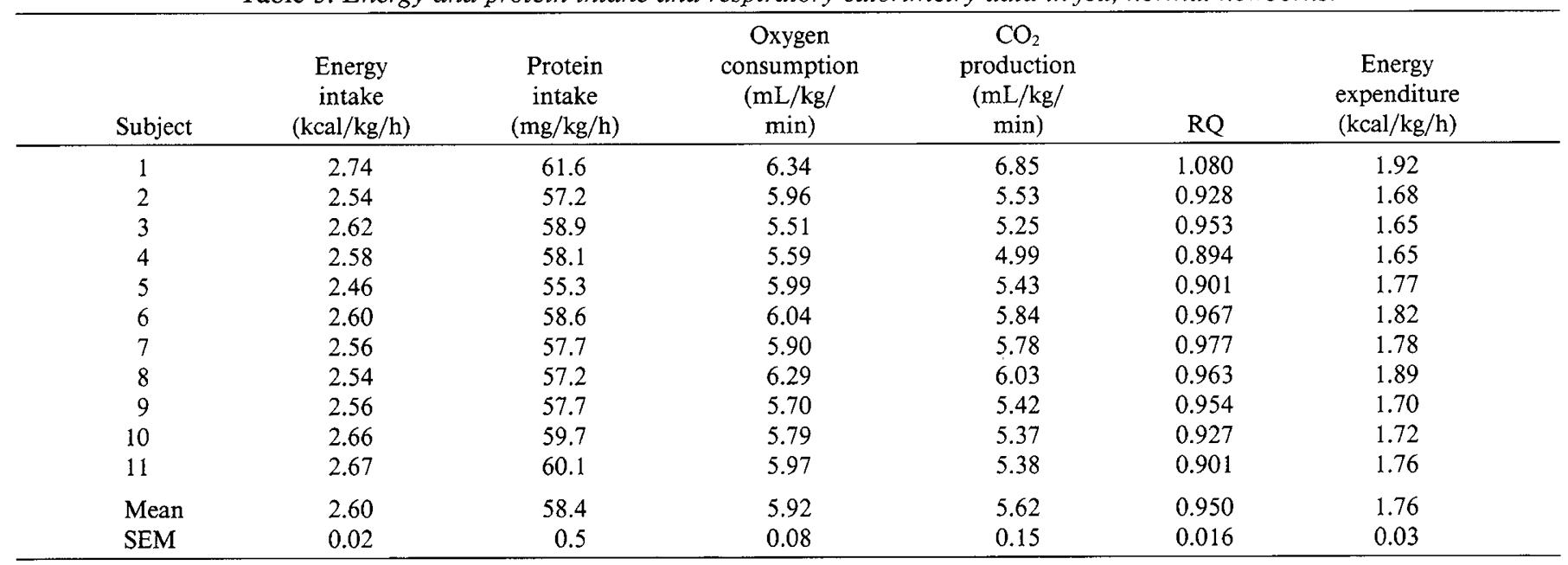




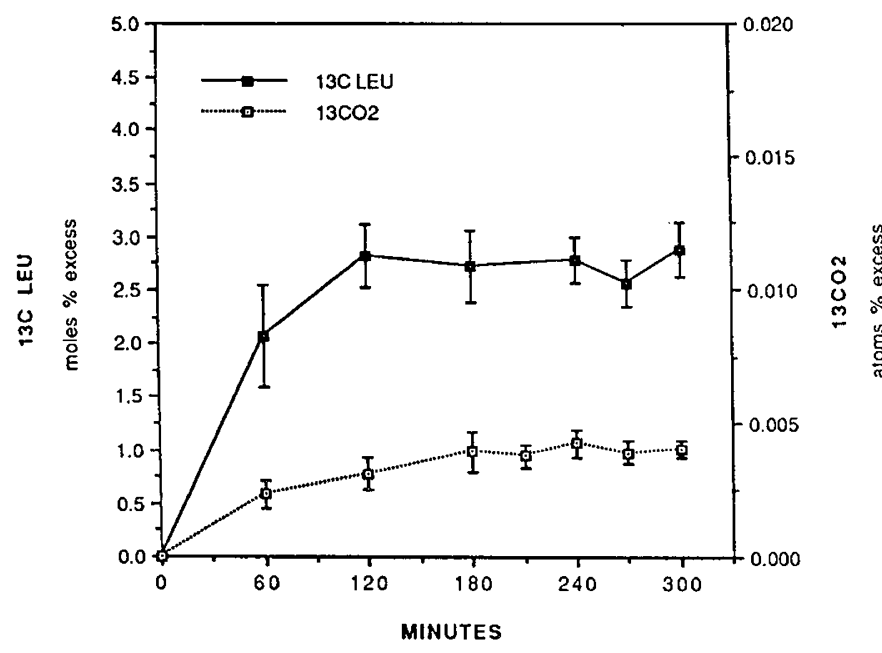

Fig. 1. Enrichments of leucine and $\mathrm{CO}_{2}$ during the studies (mean \pm SEM).

demonstrated no differences between protein breakdown rates in newborns studied during fasting or during feeding. On the other hand, the rate of protein synthesis (reflected by the nonoxidative disposal of leucine) was significantly higher in newborns studied during feeding. These results would suggest that newborns during early neonatal life accrete protein primarily by increases in rates of protein synthesis rather than by suppression of protein breakdown.

We recognize that there are limitations in comparing separate groups of newborns studied under conditions of feeding and fasting; however, we believe the comparison to be valid. Both groups of infants were studied under an identical protocol, except for the presence or absence of feeding. The length of infusion was the same for all newborns, so the extent of isotope recycling should be similar in both groups. The range of birth weight was similar in both groups, and all infants were healthy, full term, and studied within the first $3 \mathrm{~d}$ of life. Although it may have been ideal to study individual infants during both fasting and feeding, for technical, practical, and ethical reasons, this was not feasible.

It is possible that a small change in protein breakdown induced by feeding was not detected in this cross-sectional study. However, it must be pointed out that if the tracer is delivered i.v. during both fasting and feeding, there is an inherent modeling bias toward underestimating leucine flux during feeding $(7,25)$. Because some of the dietary leucine intake may be taken up in the splachnic region before reaching the systemic circulation, total leucine flux may be underestimated, thereby exaggerating the effect of feeding on the endogenous release of leucine from existing protein (protein breakdown). Despite this inherent bias, no effect of feeding on suppression of protein breakdown could be demonstrated in the present study.

Studies in human adults have consistently shown increased rates of leucine oxidation in response to feeding (2-7). In contrast, despite significant intakes of protein $(1.4 \mathrm{~g} / \mathrm{kg} / \mathrm{d})$ and leucine $(45 \mu \mathrm{mol} / \mathrm{kg} / \mathrm{h})$, newborns examined in the present study did not demonstrate higher rates of leucine oxidation during periods of feeding. Although this response is clearly different than in adults, it is not totally unexpected. Adults during feeding must replace the quantity of protein oxidized during fasting; in contrast, in newborn infants, protein must be accreted in excess of simple replenishment to support growth. Relative to adults, rates of leucine oxidation during fasting are significantly higher in newborns (8); net accretion of leucine for growth would be difficult if feeding resulted in large increases in leucine oxidation.

With data available for both feeding and fasting normal newborns, an estimate can be made of the leucine intake required to replace irreversible leucine oxidative losses. To our knowledge, these data represent the first quantification of the oxidative loss of any essential amino acid in normal newborns. Based on these leucine oxidation measurements, approximately $820 \mu \mathrm{mol} / \mathrm{kg} / \mathrm{d}$ $(107 \mathrm{mg} / \mathrm{kg} / \mathrm{d})$ of leucine intake would be required to replace irreversible leucine losses. If the rate of leucine accretion to achieve normal growth is added to this estimate, an overall leucine requirement for normal newborns (at least within the early neonatal period) can be approximated. Based on a newborn protein accretion rate of $0.91 \mathrm{gm} / \mathrm{kg} / \mathrm{d}(26)$ and a leucine content of protein of $590 \mu \mathrm{mol} / \mathrm{g}$ protein (1), the leucine accretion rate is approximately $535 \mu \mathrm{mol} / \mathrm{kg} / \mathrm{d}(70 \mathrm{mg} / \mathrm{kg} / \mathrm{d})$. Using these values for leucine oxidation and accretion, the newborn leucine requirement is estimated at $1355 \mu \mathrm{mol} / \mathrm{kg} / \mathrm{d}(177 \mathrm{mg} / \mathrm{kg} / \mathrm{d})$. This value is slightly higher than the estimated requirement of $1229 \mu \mathrm{mol} / \mathrm{kg} / \mathrm{d}$ proposed by the Food and Agricultural Organization/World Health Organization (27). It must be pointed out that the estimates of leucine oxidation are based on the plasma enrichment of leucine. Oxidation based on KIC enrichments would most likely be higher, resulting in a higher estimate $(\sim 15-20 \%)$ of total leucine requirements.

As we have previously demonstrated in fasting newborns, there was a significant correlation in our present study between birth weight and leucine flux. It must be emphasized that this correlation is not simply due to more protein mass in larger babies, because leucine flux was normalized to body weight. Differences in lean body mass are also unlikely to account for this correlation. All infants studied were in the range of normal birth weight, and the $\sim 100 \%$ difference in leucine flux between the largest and smallest babies would probably not be matched by a similar magnitude of difference in lean body mass. In addition, small for gestational age infants tend to have decreased and large for gestational age infants increased amounts of body fat (28). Therefore, differences in lean body mass between small and large infants would most likely magnify rather than diminish the correlation between leucine flux and birth weight.

The fact that a correlation between birth weight and leucine flux (and leucine from protein breakdown) has been demonstrated in two groups of normal newborns studied under different conditions confirms that a relationship exists between birth weight and protein metabolism. We do not mean to imply that this a causal relationship; it is most likely that another factor (or factors) affects both birth weight and protein metabolism. We have speculated that this relationship may be a result of differences in previous protein and energy supplies (8). This speculation is based on studies in adults, children, and fetal animals that have demonstrated that leucine flux and protein turnover are sensitive to previous dietary protein and calorie intake $(2,6,25$, 29,30 ). Lowered dietary protein intakes have resulted in decreased leucine flux in adults studied during both feeding and fasting $(2,6,25)$. In children, protein turnover has been shown to be decreased after low levels of protein and energy intake (29). Similarly, reduced protein turnover rates have been obtained in fetal rat tissues after the mother has received a restricted protein calorie diet (30). Thus, it is possible that differences in the in

Table 4. Leucine kinetics in fed and fasted newborns (expressed as $\mu \mathrm{mol} / \mathrm{kg} / \mathrm{h}$ )

\begin{tabular}{|c|c|c|c|c|c|}
\hline & Flux & Intake & $\begin{array}{c}\text { Release from } \\
\text { protein breakdown }\end{array}$ & Oxidation & $\begin{array}{c}\text { Nonoxidative } \\
\text { disposal }\end{array}$ \\
\hline Fed $(n=11)$ & $201 \pm 16^{*}$ & $46 \pm 0.3$ & $156 \pm 16$ & $31 \pm 4$ & $170 \pm 13^{*}$ \\
\hline Fasted $(n=12)$ & $164 \pm 8$ & 0 & $164 \pm 8$ & $34 \pm 3$ & $129 \pm 9$ \\
\hline
\end{tabular}

\footnotetext{
${ }^{*} p<0.05$ fed $v s$ fasted.
} 


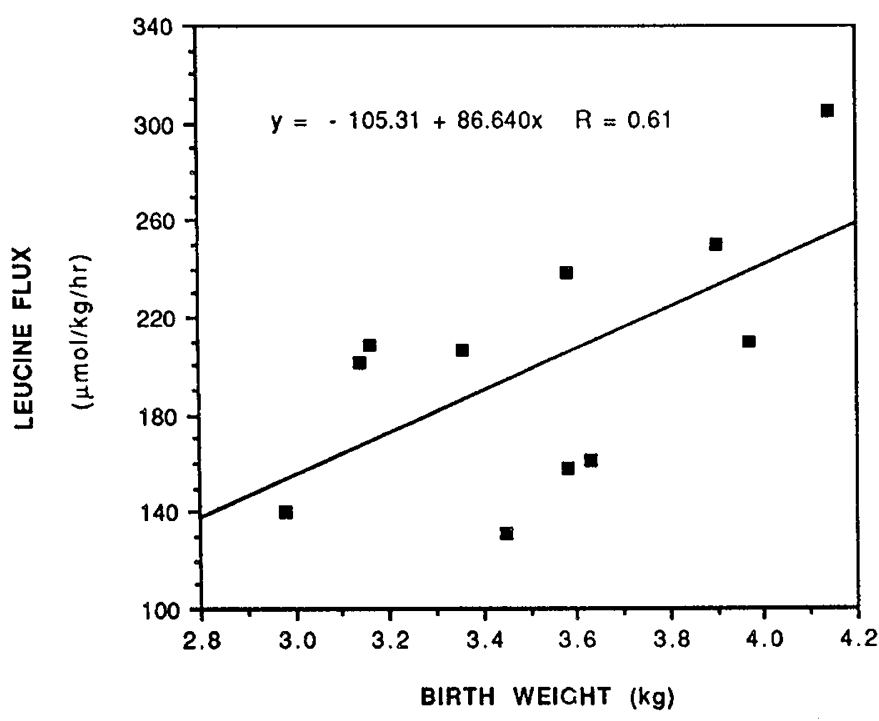

Fig. 2. Correlation between birth weight and leucine flux in feeding newborns.

utero supply of protein and energy may result in differences in birth weight and protein metabolism.

In summary, compared with fasting, newborns during feeding demonstrate significant increases in leucine used for protein synthesis; rates of leucine release from protein breakdown during fasting and feeding are similar. This suggests that newborns may accomplish protein accretion primarily by increases in protein synthesis (rather than suppression of protein breakdown). Rates of leucine oxidation are nearly identical in newborns during fasting and feeding. Therefore, an estimate can be made of the minimal leucine intake required to replace irreversible leucine oxidative losses $(816 \mu \mathrm{mol} / \mathrm{kg} / \mathrm{d}, 107 \mathrm{mg} / \mathrm{kg} / \mathrm{d})$. When added to the calculated rate of leucine accretion, an overall estimate of leucine requirement can be made $(1355 \mu \mathrm{mol} / \mathrm{kg} / \mathrm{d}, 177 \mathrm{mg} / \mathrm{kg} /$ d). As has been previously shown in fasting newborns, there is a significant positive correlation between birth weight and leucine flux in full-term infants during feeding, suggesting a relationship between birth weight and protein metabolism. It is speculated that this relationship may be a result of differences in previous (presumably in utero) protein and energy supplies.

Acknowledgments. The authors thank Cheryl A. Karn, R.N.C. for her expert assistance in performing these studies and Kim Brickley for her help in preparing the manuscript.

\section{REFERENCES}

1. Waterlow JC 1984 Protein turnover with special reference to man. Q J Exp Physiol 69:409-436

2. Motil KJ, Matthews DE, Bier DM, Burke JF, Munro HN, Young VR 1981 Whole-body leucine and lysine metabolism: response to dietary protein intake in young men. Am J Physiol 240:E712-E721

3. Clugston GA, Garlick PJ 1982 The response of protein and energy metabolism to food intake in lean and obese man. Hum Nutr Clin Nutr 36C:57-70

4. Rennie MJ, Edwards RHT, Halliday D, Matthews DE, Wolman SL, Millward DJ 1982 Muscle protein synthesis measured by stable isotope techniques in man: the effects of feeding and fasting. Clin Sci 63:519-523
5. Hoffer LJ, Yang RD, Matthews DE, Bistrian BR, Bier DM, Young VR 1985 Effects of meal consumption on whole body leucine and alanine kinetics in young adult men. Br $\mathbf{J}$ Nutr 53:31-38

6. Young VR, Gucalp C, Rand WM, Matthews DE, Bier DM 1987 Leucine kinetics during three weeks at submaintenance to maintenance intakes of leucine in men: adaptation and accommodation. Hum Nutr Clinical Nutr $41 \mathrm{C}: 1-18$

7. Melville S, McNurlan MA, McHardy KC, Broom J, Milne E, Calder AG Garlick PJ 1989 The role of degradation in the acute control of protein balance in adult man: failure of feeding to stimulate protein synthesis as assessed by $\mathrm{L}-\left[1-{ }^{13} \mathrm{C}\right]$ leucine infusion. Metabolism 38:248-255

8. Denne SC, Kalhan SC 1987 Leucine metabolism in human newborns. Am J Physiol 253:E608-E615

9. Motil KJ 1988 Protein needs for term and preterm infants. In: Tsang RC, Nichols BL (eds) Nutrition During Infancy. Hanley \& Belfus, Inc, Philadelphia, pp 100-121

10. Denne SC, Kalhan SC 1986 Glucose carbon recycling and oxidation in human newborns. Am J Physiol 251:E71-E77

11. Matthews DE, Schwarz HP, Yang RD, Motil KJ, Young VR, Bier DM 1982 Relationship of plasma leucine and a-ketoisocaproate during a $\mathrm{L}-\left[1-{ }^{13} \mathrm{C}\right]$ leucine infusion in man: a method for measuring human intracellular leucine tracer enrichment. Metabolism 31:1105-1112

12. Schwenk WF, Beaufrere B, Haymond MW 1985 Use of reciprocal pool specific activities to model leucine metabolism in humans. Am J Physiol 249:E646E650

13. Thompson GN, Pacy PJ, Ford GC, Merritt H, Halliday D 1988 Relationships between plasma isotope enrichments of leucine and $\alpha$-ketoisocaproic acid during continuous infusion of labelled leucine. Eur J Clin Invest 18:639643

14. Vazquez J, Paul H, Adibi S 1986 Relation between plasma and tissue parameters of leucine metabolism in fed and starved rats. Am J Physiol 250:E615E621

15. Adams RF 1974 Determination of amino acid profiles in biological samples by gas chromatography. J Chromatogr 95:189-212

16. Mullen KD, Denne SC McCullough AJ, Savin SM, Bruno D, Tavill AS, Kalhan SC 1986 Leucine and protein metabolism in stable cirrhosis. Hepatology 6:622-630

17. Tserng KY, Kalhan SC 1983 Calculation of substrate turnover rate in stable isotope tracer studies. Am J Physiol 245:E308-E311

18. Kalhan SC, Ricanati ES, Tserng KY, Saving SM 1983 Glucose turnover in chronic uremia: increased recycling with diminished oxidation of glucose. Metabolism 3:1155-1162

19. Steele R 1959 Influence of glucose loading and of injected insulin on hepatic glucose output. Ann NY Acad Sci 82:420-430

20. Lusk G 1923 Animal calorimetry: analysis of the oxidation of mixture of carbohydrate and fat. J Biol Chem 49:41-42

21. Allsop JR, Wolfe RR, Burke JF 1978 Tracer priming the bicarbonate pool. J Appl Physiol 45:137-139

22. Van Aerde JEE, Sauer PJJ, Pencharz PB, Canagarayar U, Beesley J, Smith JM, Swyer PR 1985 The effect of energy intake and expenditure on the recovery of ${ }^{13} \mathrm{CO}_{2}$ in the parenterally fed neonate during a 4-hour primed constant infusion of $\mathrm{NaH}^{13} \mathrm{CO}_{3}$. Pediatr Res 19:806-810

23. Raiha N, Minoli I, Moro G, Bremer HJ 1986 Milk protein intake in the term infant. II. Effects on plasma amino acid concentrations. Acta Paediatr Scand 75:887-892

24. Maurling S, Arturson G, Zaar B, Eriksson G 1981 Energy, fat and nitrogen balance in healthy newborn infants during the first week after birth. Acta Chir Scand 147:487-495

25. Cortiella J, Matthews DE, Hoerr RA, Bier DM, Young VR 1988 Leucine kinetics at graded intakes in young men: quantitative fate of dietary leucine Am J Clin Nutr 48:998-1009

26. Fomon SJ, Haschke F, Ziegler EE, Nelson SE 1982 Body composition of reference children from birth to age 10 years. Am J Clin Nutr 35:1169-1175

27. Food and Agriculture Organization, World Health Organization, United Nations University 1985 Energy and protein requirements. Report of a join expert consultation. WHO, Geneva (WHO technical report series no. 724)

28. Sparks JW 1984 Human intrauterine growth and nutrient accretion. Semin Perinatol NY 8:74-93

29. Tomkins AM, Garlick PJ, Schofield WN, Waterlow JC 1983 The combined effects of infection and malnutrition on protein metabolism in children. Clin Sci 65:313-324

30. Johnson JD, Dunham T 1988 Protein turnover in tissues of the fetal rat after prolonged maternal malnutrition. Pediatr Res 24:534-538 